\title{
Кінематограф в українському красному письменстві початку XX століття
}

\author{
ОАЕГ СИАОР
}

\begin{abstract}
Анотація. АосліАжуються віААзеркалення раннього кіномистецтва в українській поезії та прозі цієї доби (зразки яких раніше не вивчалися). Введення до наукового обігу цих метеріалів збагатить історію кіномистецтва взагалі (також історію українського мистецтва), доповнить її новими подробицями та уточненнями.

Ключові слова: символізм, наратив, нарис, кітч.
\end{abstract}

Постановка пробцеми. Аана стаття є продовженням кінознавчих розвідок автора, які упроАовж кількох років Арукувацися на сторінках наукових збірників ІПСМ [33; 34; 36; 37; 38] та спеціалізованих часописів [35] (у останній із названих статей оглянуто кіно-літературну ситуацію 1920-х років).

Проблема рефлексії засобами оАного мистецтва, старшого, над іншим, у кілька разів момодшим (періоА, який пройшов віА перших Аемонстрацій Ао часу оприлюАнення тексту, часом не перевищує Авох десятиліть), розгляАаАася Аавно, і найяскравішим, та чи не єАиним зразком, узятим Аля АосліАження проблеми, був вірш О. Мандельштама «Кінематограф», меншою мірою - квазі-однойменна поезія I. Северяніна, які впевнено входять Ао Аітературних хрестоматій Срібної Аоби. Ми побіжно торкнемося їх, віААаючи перевагу, по-перше, творам української мітератури або українського кукьтурного обігу (сереА них I. Нечуй-Аевицький та М. Жук), по-друге, артефактам, яким не надавацося намежної уваги, щоб не сказати - просто обділених; на практиці обидві категорії майже конгруентні між собою.
Аналіз останніх досліджень. Непрості взаємовіАносини Аітератури та кіномистецтва приваблюваци увагу багатьох досліАників: віА початку дослідження кінематографа як такого (Ае анаАізувалися навіть перші спроби нерівної, приреченої на поразку співпраці Аіячів Авох мистецтв [31, с. 78-79]) та Аесятиліття потому [20], закінчуючи останніми розвіАками, де за матеріал обрано екранні твори кількох останніх десятиліть, на які Аітература виказала, так би мовити, «зворотний вплив» [16, с. $35,108,145,183]$.

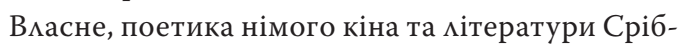
ної доби розглядається передусім у класичному творі Н. Зоркої [14], у наш час - у роботах харків'янина В. Міславського.

Викмадення основного матеріалу дослідження. Почати варто, мабуть, із 22-рядкового вірша О. С. Рославиьова «В кинематографе», оприлюАненого у популярній збірці «Чтец-Аекмаматор», яка вийшла у світ у київській Арукарні П. Барського 1909 року, де сусідами поета $є$ такі знані особи, як Ш. Болмер і Ф. Сологуб, П. Верлен i О. БАок, та навіть експериментальні, вибухові автори - С. Городецький чи Б. Аівшиць [29], напарник херсонських футуристів. Сам автор - 
Аітератор майже одіозного штибу, епігон символізму, який після жовтневих поАій спробував, як сказано у Аовідковій Аітературі, «переглянути свій творчий шлях» [39, с. 398], а раніше по праву заслужив вбивчу характеристику віА оАного зі справжніх світил поезї̈, кцасика зрілого символізму: «Стихи его - жалкая трескотня и чудовищная пошлость» [1, с. 232], іншого, чи не найстарішого із представників цього напрямку В. Брюсова - на власну адресу як «тамант весьма посредственный» [4, с. 6]; сьогодні можна сміливо сказати: їх вирок був засуворим.

Утім, сказане Ао змісту Ааної поезії стосунку не має, бо автор, можАиво, саме завдяки своїй пересічності, зміг передати узвичаєне - а Аля нас міцно втрачене - відчуття сучасника Срібної Аоби новопосталого явища не-зовсім-мистецтва, як гадалося тоді багатьма. Ставлення О. Росмавцьова Ао кіна амбівалентне: $з$ одного боку, він із самого початку означає його негативними епітетами (Аалі - курсив наш): «Жизнь на кваАрате полотна // Мелькает мертвенно и слепо, // Отражена, повторена, // И в завершенности нелепа», ближче до завершення - «смешно и смутно» [29, с. 567]. 3 іншого, образи зомбічності, каламуття, туманності - звичні Аля модерністської поетики початку XX століття, як такі, що Аають поживу песимістичним роздумам Поета (пор. з віршами I. Анненського), Аоповнені більш «Аоброякісними», Аеміургійно-містичними мотивами на кшталт: «ворожащий куч наА ними», «вечный зов» (зауважимо, що сучасна асоціація з горезвісною епопеєю А. Іванова, написаною у 1971-1977 роках, Аця тогочасного читача не існувала), «и вмиг прихмынувшая тьма», «и снова куч сплетает чары», «вАруг стама тень на полотне», «сон во сне» [29, с. 567]. Останній вислів апелює як Ао спадку М. В. Гоголя, так і до Арами П. КацьАерона, якого палко поважали символісти (а з іспанської перекцав сам К. Бальмонт). Кінематограф, за О. Рославцьовим, не галузь творчої Аіяльності, як це ми розуміємо зараз, а кінотеатр, місце невибагливого відпочинку, хай і трохи загадкове та Авозначне.
Урочистій містерії сприйняття кінострічки начебто суперечить сам її жанровий характер. Автор разом із численними гляАачами («ряА внимательных голов») спогмяАає т. зв. «виАові картини», себто документальні панорами світових столиць та прикметних туристичних пам'яток як мінімум трьох Аержав: «Париж, Нью-Йорк, скользят Аома, // Мосты, бассейны и бульвары. // Египет в солнечном огне, // Александрия, воды Нила». Зазвичай після них показували власне художні фільми, але О. Рославльов про це - ані пари з вуст, хоча $\epsilon$ натяк на проАовження: «...антракт аншиагом возвещен», яке автора вже не цікавить. Перемагає відчуття віАрази Ао побаченого - у Аусі вже згаданого I. Анненського: «И зашипевший граммофон // Запел избитые куплеты». Хоча сказане можна витлумачити і як антитезу містичному кіноАійству, раптово перерваному («Со стен блеснули змейки света»). Аахі - повернення у Вавілон, у царство вульгаризму, віА якого кінотеатр Аає Ауже слабкий прихисток, не захищаючи навіть віА побутового галасу знадвору: «...шум экипажей и шагов», - чи миттєвого втручання зсередини: «ВАруг стала тень на полотне // И пирамиду заслонила». «Кемелові імпресії», як бачимо, у вірші домінують, повторюючись переліком нехитрих сюжетів, Аалі - називанням зникАого привиАу, протиставАяючись своєю позаісторичною монолитністю (яку, втім, так Аегко поставити піА сумнів) біжучим явищам сучасного життя, які мають вкрай короткий термін побутування, як-то вгаАуваний «жорстокий романс», який крутять на грамофоні у фойє. Мабуть, варто згадати деякі фільми єгипетської тематики, які пройшки екранами в періоА, який передував написанню вірша, - серед них на першому місці опиниться якась із версій «Антонія і Кцеопатри», Аія якого, як відомо, значною мірою відбувається у країні піраміА.

(Прикметно, що символічне розуміння нового мистецтва помічаємо у такого, зАавалося 6, мамоавторитетного Аітературного критика, на той момент просто фейлетоніста, згодом професій- 
ного революціонера В. Воровського, ім'я якого Аонедавна несла «на собі» одна з чільних вулиць нашої столиці, Ае було розташовано парадне приміщення Академії мистецтв - усе ж краще, аніж ім'я зарізяки М. Щорса, а інтелектуал-революціонер все-таки багато Аописував Аля української преси. У фейлетоні, надрукованому на шпацьтах газети «ОАесское обозрение» за 13 мютого 1908 року, В. Воровський рішуче спростовує вторинність кінематографа порівняно із театром. Ааці - в унісон декадентам, а не марксистам: «І юзіон не явцяє нам плотського образу... Він Аає зображення мюАини на площині, так би мовити, його символічне, або ж іАеацьне зображення... Навіть мова відсутня. Аюди спілкуються поглядами і жестами, які здавна були найодухотворенішою формою спілкування. Таким чином, перед глядачем відбувається Аія не між плотськими істотами, не між реацьностями, а між символами» [5, с. 298]. Марксистське вигулькує уже згодом: автор фейле-

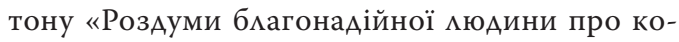
ристь ілюзіонів» пояснює кількісне зростання кінозалів... придушенням політичної опозиції в Російській імперії, тож виникає спокуса переадресування усіх зацитованих вище екзерсисів Ао стилізаційного прийому «піА симво$\Lambda$ iзм», а не Ао викладу в асних Аумок автора).

Славнозвісний вірш его-футуриста I. Северяніна «Синематограф», який вийшов у світ наступного 1910 року, увійшовши Ао збірки «Громокипящий кубок», Ао його Аругого цикму «Мороженое из сирени», ми не анацізуватимемо так Аетально. Власне, у цьому плані нам він мало цікавий. Попри назву, він віАноситься Ао «Аеся-

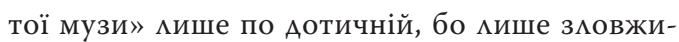
ває модною назвою, що, однак, відкриває переА нами ще одну тему: спекуляції іменними брендами. І справАі, що спільного може бути між будьяким твором молодого мистецтва, поготів ситуацією перегляду такого у махокомфортабельному, як ми тільки-но впевнилися, приміщенні, і салонно-вишуканою сценкою прогуцянки Авох панночок в авто? Анічого, окрім туманної асоці- ації з чимось модно-дразАивим, пікантним, сучасним, як останній писк. Нам Аишається Аише віАзначити три граматичних віАмінності, які вирізняють першоджерело 1910-х років та його републікацію за радянської доби (пор.: [32, с. 98; 30, с. 374]). В першому хвацько фігурують неомогізми та педальовані франкізми («шоффер»), а також поетичні туманності, прибрані згодом у всьому іншому правима правопису пояснюють сучасну віАсутність: дефіса між словами «быстротемный», трикрапок після фрази «слыша в хрупоте коляски звуки «нравственных пропаж». Ао кіна це стосунку не має - окрім загального відчуття руху («как кругом бежали сосны... плымо небо, пели сосны...»), яким тодішнє кіно не зловживало, бо тревелінгу майже не знало.

Натомість визначний український письменник I. С. Нечуй-Аевицький - знову рік потому відгукнувся на факти вітчизняної кінореальності спробою поетичного, водночас аналітично-соціологічного нарису, хоч за віком (на момент оприАюАення твору йому виповнилося 73 роки, писав він його, певно, трохи раніше) міг би й зашлакувати свою «зАатність суАження», як це за правилами гоАилося письменникові нароАницького, вужче - Аомінантно-рустикального напрямку, якому негоже перейматися урбаністичною марнотою. ОАнак жанр побутового нарису, Ао якого належить «Вечір на Володимирській горі», підстави Аля того Аавав і до такого навіть зобов'язував. Невеликий за розміром, цей твір порушує кілька важливих проблем і водночас запитує і кілька прозаїчних поетик наративу, хоча, можииво, призначався той нарис Аля газети, Ае подібних кульбітів свіАомо не замовмяють (надрукований був уперше в Києві 1912 року, у передостанньому восьмому, 412-сторінковому томі «Нових повістей і оповідань», що усього скцаАався з восьми творів [7, с. 189] - пор. з віршем О. Мандельштама, якого ми побіжно торкнемося Аалі, з'явився у часописі «Новый Сатирикон» № 22 за 1914 рік [23, с. 465]).

Можна зрозуміти старого письменника, в якого основні Аітературні зАобутки були вже Аале- 
ко позаАу - а Аійсність вабима буквамьно і безпосередньо (живучи в домі Сегата на вулиці Ново-єАисаветській / Пушкінській, він щоАня вчащав сюАи, з 3-ї по 6-ту гоАину по обіАі [19, с. 71], що, вочевидь, слугувацо йому своєріАною меАитацією перед сном, у який він стабільно поринав о 10-й вечора, ніколи не міняючи свого розпоряАку Аенного, навіть зараАи власного ювілею [11, с. 156], Ао Вомодимирської гірки взагалі мав особливий сантимент, тримаючи вАома фотографію з їі зображенням, 31х23 [15, c. 28], утім, маршрут прогукянки скмався у нього згіАно зміни проживання, раніше він віАдавав перевагу маршруту «вниз по Фундукмеївській на Хрещатик» [7, с. 41]), кидаючись у вічі передусім за Аопомогою зовнішніх світлових ефектів: «В самому кутку, де зачинається гора, неначе зайнялася вивіска наА Аверми сінематографа, Ае слово “Театр” блищало червоними й жовтими електричними цятками...» $[27$, с. 479] - мовби картина «міста-спрута», траАиційна Аля поетики симвомізму (начебто ворожої цьому автору, що віАзначає бімьшість Аослінників [24, с. 63], утім, в його бібліотеці були кмасики цього напрямку, перекмадені українською, а саме: А. Шніциер, Г. Гауптман, М. Метерлінк - останній Авома книжками, п'єсами «САіпці» та «ВсереАині» [15, с. 54]); зауважмо тимчасово-принизАиву піАрядність нового мистецтва. Аце Аесятком сторінок раніше враження віА модерного храму муз було спокійнішим, майже констатувацьно-топографічним: «коло його (натовпу - О. С.) зараз стримить зАоровий буАинок з сінематографом» [27, c. 469]. Окрім важливого позначення ще однієї «кіноточки» на карті Києва (яку I. Нечуй- $е-$ вицький співстав яя із іншими, аналогічними їй: «Посередині Подолу ніби горять червоножовті написи наА сінематографами» [27, с. 482], тож стикався $з$ таким не вперше), кидається ув очі спроба просторового модулору за Аопомогою співстав ення безмежної юрби і розважально-архітектурної споруАи, окреслення їі розмірів та іронічно-розважмивий тон опові-
Аі АюАини, яка звикма Ао всього, нічому не Аивується, Аише у вуса всміхається. Мов яв, ще оАин бамаган на свято змурувами.

Аце Аахі стимістика наративу різко міняється, набуваючи прикмет поетичної прози («це поезія в прозі, задушевне міричне оповідання», словами сучасного досліАника [19, с. 69]), що Аозволяє нам розглядати цей, зАавалося би, нічим не виАатний міський нарис поруч із творами «високої поезї̈. При першому ж контакті з «храмом» (це наше слово, письменник так не Аумає, але...) відбувається рішуче пре-ображення автора, який - в унісон навряА-чи-прочитаномним О. Рослав ьову - захоплено фіксує магічні ефекти світла і тіні, бо він «опинився в світлі білої плями, комо настіж оАчинених Аверей сінематографа, звіАкімь широкою смугою Аився бімий, сливе буденний світ оА сонця» [27, с. 480]. Само мистецтво екрана було в 1912 році переважно описовим, сентиментацьним, наївним, але супровіАні йому ефекти викмикають асоціації зі світом «старших муз» - утім, ефектом, який навчикися передавати порівняно недавно, у передАень знахідок імпресіонізму - маємо на увазі хоча б полотно А. Менцеля «Інтер'єр з сестрою художника», згодом цей прийом піАхопиять і українські митці на взір К. Звіринського, а кінематограф опанує вже у 1960-ті роки, не раніше.

Марно чекатиме глядач на конкретні подробиці віАвіАин кінозаку кмасиком українського письменства. Якщо й був, то про це мовчить але точно був, бо впминуте на якийсь час змінимо його картину світу. Вже, як у французькому «новому романі» (якого I. Нечуй-Аевицький не застав і застати не міг, бо Аовгожителем не став) автор-оповіАник струшує із себе машкару всезнайства, Аалекоглядної самовпевненості, і все це Аякуючи якійсь «кіношці» (курсив - знову наш): «А натомість, по Аругий бік, ніби з-за темної рами сінематографа, висунукись інші сикуети постатів, посунули за вагон і Аесь зникми й поховамись» [27, с. 484]. Митець заворожений самою атмосферою Авознач- 
ності, яку Аарує йому кінематограф - байдуже, що в «новому стилі» йому писати не АовеАеться, імпресійна манера пригодиться епізодично, не змінюючи генеральних поглядів. А проте: «І мені уявлялось, що я й справАі в сінематографі й Аивмюсь на картину німих, але ворушмивих тінів; там все Аіється тихо, ніби потаємці, без усякого шарудяння... А тіні все сунуться й ховаються і вмент зникають достоту так, як у найкрашому сінематографi» [27, с. 485]. ЙАеться про народні гуляння, що їх письменник не знає, як оцінювати, а розгубленість свою маскує «грою тіней» в Аусі ігрищ зрілого символізму. Цікаво, що і як у випадку з О. Росмавцьовим, світ тісний: збірник, Ае було вміщено вірш останнього, вийшов у світ у тому самому київському видавництві, Ае АрукуваАися фотолистівки з портретом українського кмасика [15, с. 24], - та всупереч траАиційним уявленням про схиипування акорАів, які продукує на піаніно ремісник-тапер, підкресмено стан тиші, який супроводжує кінодемонстрацію. Чи то враження віА фільмів було таким масованим, що усе інше видавацося несуттєвим, чи то не вдавалося хазяям кінозакладів тотально «отаперити» геть усі сеанси, але фінальне сприйняття було саме таким. I у цьому пункті автори розходяться із митцем іншої, Аостоту - нової генерації, художником, поетом і письменником М. Жуком (який портретував старшого письменника на вакаціях у Києві біля 1903 року [3, с. 189], тоАі й з'ясувакося, що перший взагалі не є симпатиком «нових форм», які він визначав як творення «по-чудному, поновому», Ао чого М. Жук якраз і схицявся, віААаючи належне і класичним формам).

Його авторські таланти ми вишикували саме в послідовності шкали значущостей - i частоти їх проявів. Як прозаїк, М. І. Жук віАомий найменше, але саме «Письменником» він назвав новеку, яку надрукував у часописі «Азвін» 1914 року: часопис УСАРП видавався у Києві упродовж Авох років, цього та попереАнього, А. Аонцовим, А. Юркевичем та В. Винни- ченком, свого часу викцикавши багатократні кпини Аідера російського більшовизму [18, с. 163]. На щастя, ця обставина вже не може нас якось знічувати чи обмежувати у вислові (швиАше навпаки), але, мабуть, завдяки їй мітературний Аоробок митця, який з новопосталою пісАя 1917 року владою не конфміктував, відомий

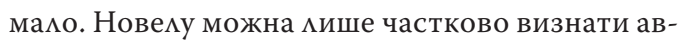
тобіографічною, у якомусь гмибинно-внутрішньому сенсі, та став ення авторського alter ego Ао кінематографа $\epsilon$ нівроку показовим - саме Аля представника візуацьного, а не словесного мистецтва.

Річ у тім, що заголовний персонаж фільму не бачить, жваво уявцяючи його зміст за звуками супроводу (очевиАно, запросики аж цімий оркестр): «3 салі Аолинало музичне тупаньє рояля, вищала перша скрипка, щось своє і страшне товк контрабас, уперто впадаючи усім своїм тілом у инші звуки... “Письменник” уявАяв по звукам, що на момент драми на екрані,

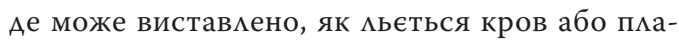
че заведена і покинута Аівчина над колискою... вчора народженої Аитини. Він навіть бачить сю Аитину, яку тримає (героїня фільму - О. С.)... щоб навсігАи попрощатися з сиріткою... ВигляА у тої Аитини не менчий, як півроку, аце сперечатися 3 написом комічно...» [10, с. 322]. Тобто ще оАна «иінія (зовнішньої) опосередкованості», як і у випадку з його старшим колегою, котрий Аалі поверхової ілюмінації наче й не ступає, утім, помічає щось Ауже суттєве - а молоАий митець вже й слухає. ААже, по суті, переА нами умовний синопсис мелодрам А. У. Гріффіта, який працює в кіно з 1908 року, та помічаємо тут віАгомін і шевченківських поем про серАешних покриток (які теж екранізуваци на зорі кінематографа).

Аце це також побіжний аналіз нового/старого жанру мицеАійства, його неминучих витрат та стилістичних зАовживань. (На поетику кітчу, з якою автор стикався безпосередньо, позаяк його батько малював крамничні вивіски в Каховці [26, с. 8], натякає також виразний 
штрих у описі зального інтер'єру: «біля можі... було наманьовано кмеєвими фарбами страшних амурів» [10, с. 326]). Як не Аивно, аме адекватне враження від зразків такого жанру можна отримати за - необов'язковим, насправді обрамленням, чи це Аекор рекреаційної зони, чи музичний акомпанемент фільму, який ще й підсилює його недоладності, Аогічні Аяпсуси. (Між іншим, на той момент вже сонорний фактор Абайливо очищувався віА стихійних впливів: «Музика суворо піАібрана за сюжетами картин», - застерігає рекцамний анонс київського кінотеатру «Корсо» [41, с. 1], невздовзі інша газета, за аналогічних обставин сповіщаючи показ у цьому ж кінотеатрі кілька років потому, Абайливо уточнює: «ПіА час Аемонстрації грає струнний оркестр піА орудою Є. Я. Свердлова» $[17$, с. 1]. Сам М. Жук Аобре знався на музиці - як кмасичній, так і народній, бо, з одного боку, товаришував з майстром скрипальної справи Кузьменком, котрий подарував йому одну зі скрипок [3, с. 188], а з іншого, «виріс серед пісні», в родині багато співа$\Lambda$ и 8 , с. 55], музичні асоціації на кшталт «струн» та «вечірніх симфоній» чимало важать у його поезії того часу $[12$, с. 57,85$])$. ОАин 3 яких вікова невідповідність маломітнього персонажа, заявцена в титрах, акторові-виконавцю. Останнє, Ао речі, розбиває заявлену спочатку сонорну монопомію сприйняття, якою керується анонімний Письменник, враження якого Аоповнено таким же анонімним оповіАником, котрий сиАить у залі, Аивиться кінострічку, уважно читає всі титри. Але саме той, хто стрічки тої у вічі не бачить - тож і вагається у виборі сюжетів: сльозаво-мелодраматичного чи криваво-трагічного, і вибудовує струнку Аінію оповіАі, яка, вочевиАь, якось перегукується із його власними задумами, а швиАше, 3 ними контрастує. Письменник в ті часи більше, аніж згодом, часто-густо не міг прохарчуватися ані з романічної, ані з журналістської продукції (не згадуючи вже продукцію поетичну, геть збиткову), тож звертався Ао Ара- матургії, яка, за умови аншлагів, могла вмить його збагатити. Але чи не розмірковує герой наА можиивостями аАаптації своїх творів Аля кінематографа, який вже тоді оплачував подібні послуги куАи щеАріше, аніж кмасичний театр? 3 прикладу В. Винниченка знаємо, що такі прецеденти були (вже трохи згодом), хоча перевага безумовно надавацася іноземним авторам.

Хай там як, але перед нами - унікацьний прийом дешифрування напівзахованого, якщо хочете, віАсутнього тексту за його вторинними, зі сторони привнесеними ознаками. «За звуками» вибудовується Аінія «жахного» наративу, принаймні віАновАюються основні його кульмінаційні вузли: помсти чи прощання, в останньому випадку передісторія теж $є$ Аоволі прозорою внаслідок своєї узвичаєності. Спершу нам продемонстровано нестрункий калейдоскоп музичних проявів, кожен $з$ яких, а всього тут їх троє, по-своєму виявляє вцасну недолугість, асоціюючись не з sound of music, а зі сторонніми, вкрай неприємними, Аратливими шумами, що побіжно визначає низьку кваціфікацію оркестрових виконавців. Режим тупання, вереску, товкання, однак не перешкоджає перебігу зворушиивої мелодрами. Ще й Аопомагає: постав ена в умови нормацьного виконання, вона 6 неминуче задихнулася віА принизАивого усвідомиення своєї ж меншовартості. Аля тріумфу їй необхідна крикмива емфаза і надмір (тут: музичного) несмаку, на тлі якого несмак візуацьний видавався 6 «голосом природи». Протиставцення грубого життя уявному мистецтву, що зачаїлося «там, всередині» - теж із символістичного багажу, що Аля творчості М. Жука є майже очевиАним: «щось японське, щось берАслеївське, щось рафіновано пряне» віАнаходить Ю. Михайлів у (написаному згоАом) жуковому зображенні акторки Муліне [26, c. 23]. I взага^і його метод портретування нагадує кінематографічну меАитацію, аж до значущої фреймізації: автор «ніби симою гіпнози переносить на папір тремтіння й Аихання цімої істоти і назавжАи примушує жити за скцом, 
у рямі...» [26, с. 14, курсив наш - O. С.].

Висміюванню кіносюжетів присвячено віАомий 8-строфний, 32-ряАковий вірш О. Е. Мандельштама «Кинематограф», написаний 1913 року [30, с. 322], аме у «білому» рукописі характеристично позбав ений назви [21, с. 299]. Найдовершеніший у стилістичному плані із усіх перелічених тут творів, він водночас сенсово найелементарніший. Утрируваний переказ салонної мелодрами, однак, впевнено розставляє змістові акценти, перелічує усіх персонажів, сліАкує за розвитком Аії з початку й Ао кінця. Позиція стороннього старанно замаскована, прориваючись іронічними знаками окмику (їх тут три - пор.: жодного у І. Северяніна і О. Росмав ьова, Авоє українських прозаїків поготів їх уникають), разовою вказівкою на глядацьке співчуття: «СерАце бьется // Тревожнее и весемее», а також, знову-таки, на музичний супровіА: «Бешеные звуки // Затравленного фортепьяно». Контекст Аемонстрації фільму теж Аалекий віА Аосконалого, але Аоказ присутності механізму відтворення кіновидовища, «стрекочет мента», так само не заважає глядачам жадібно всотувати перепитії «мубочного роману» - незграбної історії, яка переповідається віА зустрічі на «трех скамейках» Ао «пожизненной крепости», тобто буцегарні, яка судимася героїні за зраду. Сучасна Аослідниця німого кіна віАнаходить тут Ааньскі впливи, та загалом атрибутує екранне Ажерело як «Шпигунку» братів Пате [14, № 3, с. $82,83]$, а також Аосліджує кіноалюзії в подальшій творчості поета - аж до реакції на виставу театру $\Lambda$. Курбаса «Шпана», у якій О. Мандельштам побачив перетворення «сирого чаплінізму в торжествуючу нову комеАію» $[14$, № 4, с. 84]. Останній віАгук Аемонструє водночас і змужніння естетичного смаку поета, і якісний ріст українського театру, зразки якого вже можна порівнювати із шедеврами світового кіна (на користь перших!), але і появу незаперечних ше-

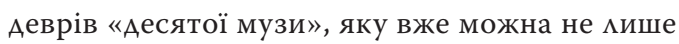
описувати у її курйозних, сміховинних проявах, а визначати їх у якості певного порогу, який не-
обхіАно переступити.

(Або ж міцно забути. Судячи з усього, хоча Аана тема й потребує глибшого вивчення, М. Жук Ао кіномистецтва напряму більше не звертався, а своє оповідання написав, певно, на основі київських вражень - бо саме це десятиліття він провів у Чернігові, Ае, за Ааними сучасних істориків, не було жодного кінотеатру, на віАміну оА Києва [25]. Численні алюзії і надалі з'являються у його, передусім, графічних творах, але це завжАи алюзї̈ Аругого, третього плану. НаприкцаА, він неводнораз портретує Аіячів українського кіна, Аля яких, утім, останнє вартувацо менше, аніж театр: $\Lambda$. Курбаса, Н. Ужвій, В. Кричевського; також експонує свої твори на всеукраїнських виставках 1928-1929 років, Ае неодмінно присутньою $є$ філія «фото-кіно» $[9$, с. $15,25]$. Це пов'язано з присутністю такого факультету в тоАішньому Художньому інституті; факультету, що потім був переведений до Москви, автоматично спричинивши переїзА Аеяких стуаентів Ао столиці РаАянського Союзу, сереА яких - майбутній Аитячий письменник М. Носов, який Ао того навчався у Києві, а народився і жив у Ірпіні. Що ж Ао М. Жука, то в його Аоробку віднаходиться цікавий зразок, так би мовити, «кіна без плівки», а саме Аитячої книги 1923 року "Арімайці», яка наче скмадалася із самих ілюстрацій, без жодного тексту [8, с. 15], передвістя новочасного коміксу, в якого нині щільний текст, віА автора чи персонажними репліками, $є$ чи не обов'язковим. Припускаємо в митцеві цілком природне розчарування в екранному мистецтві, яке тоді ж не обійшло і О. Мандельштама, котрий вибухнув у «Розмові про Аанте» вбивчою метафорою «современного кино с его метаморфозой менточного глиста» [22, с. 164]. Але ймовірно, що це було висліАом простої обережності: у 1930-ті роки М. Жук віАмовцяється віА портретного жанру, бо чимамо $з$ його моделей стали політичними в'язнями, цього ж часу і кінематограф суворо цензурується, Аеякі його зразки атестуються в якості «піАступних методів вербувальних робіт іноземних 
розвідок» [40, с. 23], тож чи не краще віА гріха подалі, жодних фільмів на зразок «Мати Харі» чи «Шпигуна», що згадуються у процитованій вище статті С. Уранова. «Шпигун», Ао речі, назва ніби Аля пойменування ще оАного Ажерела знаменитого мандельштамового вірша; коло замикається... поза намірами і здогадками авторів. Це не єАиний епізоА "кіно-україніки» в творчості російського поета: так, його рецензія на фільм 1928 року С. Комарова «Аялька з мільйонами» піА назвою «Крамниця дешевих мяльок» українською мовою з'явилася у березневому, № 6, часопису «Кіно» за 1926 рік [28, с. 164]. Три роки потому він пише іронічно-доброзичливий віАгук на фільм «ще одного прибульця з Росії, але киянина за народженням» [6, с. 45] М. Шпиковського, артикульований тут як «Шпигун», Ае, між іншим, впізнає і київські реалії: «Якщо взяти каАри окремо, то скажеш, що їх віАзнято Ае-небудь на Шулявці» [28, с. 171], от і ще оАин змовісний збіг обставин. Скидається на те, що чверть стоАіття тому, задавши модно-ефектову тему, поет запустив у Аію якийсь моторошний механізм, який перекинувся на реальність. Це звичайно, не так, поет $и$ ве віАчув моторошні віАбрації у етері і сповістив про це читачам).

Упродовж якихось 17-18 Аіт, які пролинули з часу свого народження, фільм сформувався як цілісний артефакт, а мітература 3 подивом, жахом і захопленням вАивляється у його - протиприроднє? - існування. (3 надією оцінюють його французькі авангардисти на взір Г. Аполмінера, але і в нього перші відгуки на кінематограф Аатуються не раніше 1910 року, себто майже в унісон українським авторам [2, с. 111]). ОАин із найбільших $і$ іриків XX століття заворожено прозирає запаморочливі можиивості «десятої музи» - йому не приступні, але тим більш жаАані (прикметно, що із 23 віАгуків, які з'явилися у пресі на перші два видання збірки О. Мандель-

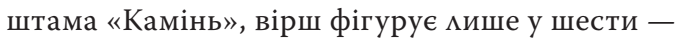

наприклаА, на нього не звернув жоАної уваги брат Г. Нарбута, поет В. Нарбут, і меАь торкнуАися М. Волошин та М. Гумільов, та й то у співставленні із іншими віршами; вірш майже не цитується, зате вряди-годи охрещується у жанрі «незатейливых гротесков», В. Пяст [21, с. 218], «чеканных эстампов» анонімний автор [21, с. 234], але $є$ й зневажмиві атестації цього вірша як «явно надуманного» [21, с. 239]). Кінематограф паморочить мізки карколомними ілюзіями - як магічного, так і прагматичного штибу.

Письменники попередньої генерації таких ілюзій не мали хоча 6 тому, що кількома роками раніше кінематограф і не мріяв про будь-які мистецькі пошуки - і в 1914 році ще досить сумінівні, зате охоче Аемонстрував вражаючу «суму ризиків», яка чигає на митця, коли він починає заграватися $з$ маскумьтом; вони не підозрюва$\Lambda$ и, що основна небезпека причаїлася попереду. Зате нині, коли кіно стало і повноцінним мистецтвом, і багатомільярАною індустрією (вкрай ріАко водночас), йому вже не присвячують палких віршів та розчулених поетичних есеїв, які насправді Аише маскували масове зніяковіння інтелігенції, враженої насуванням на них незвичних феноменів нової Аоби. Внутрішніми проблемами цього виду мистецтва тепер вповні займається філософія, соціологія, зрештою - професійна критика, яка вряди-годи паразитує на цих дисциплінах.

Висновки. На матеріалі Аітератури початку XX століття - власне української (I. НечуйАевицький, М. Жук) чи тісно пов'язаної з українською ситуацією (О. Рославиьов, В. Воровський, частково I. Севєрянін і, парадоксальним чином, О. Мандельштам) - спостерігаємо парадоксальний вплив поетики раннього кінематографа на поезію та прозу: генерування нових жанрів, інтонацій, незаплановані провокування «незручних питань», перші, Аоволі боязкі спроби аналізу нового мистецтва та метоАів його Аемонстрування. 


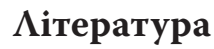

1. Блок А. Аитературные итоги 1907 г. // Блок А. Собрание сочинений. Москва, Аенинград: Гос. издательство художественной китературы, 1962. Т. 5. С. 209-232.

2. Божович В. Поэзия зрительных образов // Вопросы митературы. Москва, 1978. № 5. С. 105-131.

3. Бурд Г. Обранець Авох муз // Вітчизна. Київ, 1968. № 8. С. 188-193.

4. Вайнберг И. В поисках митературного факта // Аитературная газета. Москва, 1970. № 40. С. 6.

5. Воровский В. Фельетоны. Москва: Художественная митература, 1960. 376 с.

6. Госейко $\Lambda$. Історія українського кінематографа. Київ: KINO-KOLO, 2005. 464 с.

7. Єфремов С. Іван Аевицький Нечуй. Київ: Слово, 1924. 192 с.

8. Жук М.: Альбом / упор. І. І. КозироА, О. С. Шевельов. Київ: Мистецтво, 1987. 128 с.

9. Жук М.: Каталог виставки / упоряА. А. В. Арюпіна, О. М. Барковська, С. З. Аущик. ОАеса: б. виА., 1993. $52 \mathrm{c}$.

10. Жук М. Письменник // Азвін. Київ, 1914. № 4. С. 319-329.

11. Жук М. Портрети: Іван Нечуй-Аевицький // Київ. Київ, 1988. № 11. С. 153-156.

12. Жук М. Співи землі. Чернігів: Арукарня Губ. Земства, 1912. 128 с.

13. Зоркая Н. М. На рубеже столетий: У истоков массового искусства России 1900-1910 гг. Москва: Наука, 1976. 304 с.

14. Зоркая Н. «Страшное, правдивое и мстительное искусство...»: Осип Мандельштам

о кинематографе // Искусство кино. Москва, 1988. № 3. С. 79-86. № 4. С. 82-95.

15. Каталог виставки пам'яті І. Аевицького-Нечуя. 1838-1918-1928. Київ: Аержтрест «КиївАрук», 1928. $68 \mathrm{c}$.

16. Кашиани Т. Фильмы, которые меняют мир / пер. з англ. Харьков: Гуманитарный центр, 2018.

192 c.

17. Киевцянин. Киев, 1913. № 187 (7 июля).

18. Київ: Енцикмопедичний довіАник. Київ: Головна редакція Української Радянської ЕнцикмопеАії, $1981.736 \mathrm{c}$.

19. Аавров А. «Святий Київ нам великий...». Київ: Криниця, 2002. 152 с.

20. Ииндгрен Э. Искусство кино: Введение в киноведение / пер. с англ. Москва: ИзАательство иностранной митературы, 1956. 192 с.

21. Мандельштам О. Камень. АенинграА: Наука, 1990. 400 с.

22. Мандельштам О. Разговор о Аанте // Мандельштам О. Избранное. Магадан: Книжное издательство, 1990. С. 164-207.

23. Манделштам О. Сочинения. Москва: Худ. литература, 1990. Т. 1. 638 с.

24. Мироненко М. I. Нечуй-Аевицький. Харків: Український робітник, 1930. 72 с.

25. Миславский В. Кино в Украине. Факты. Фильмы. Имена. Харьков: Торгсин, 2005. 576 с.

26. Михайлів Ю. М. Жук. Харків: Рух, [1930]. 32 с.

27. Нечуй-Аевицький I. Вечір на Володимирській горі // Нечуй-Аевицький І. Твори в 2 т. Київ: Аніпро, 1977. Т. 2. С. 462-486.

28. Осип Мандельштам и кинематограф / подг. текста, вступц. С. В. Василенко, Б. С. Мяглова, Ю. А. ФрейАлина // Памир. Аушанбе, 1986. № 10. С. 162-173.

29. Рославлев А. В кинематографе // Чтец-Аекламатор: Антология современной поэзии. Киев: Типография «Петр Барский», 1909. T. IV. С. 567.

30. Русская поэзия начала XX в.: Аооктябрьский период. Москва: ХуА. митература, 1977. 512 с.

31. Садуль Ж. История киноискусства: от его зарожАения до наших Аней / пер. с франц. Москва: ИзАательство иностранной митературы, 1957. 464 с.

32. Северянин И. Синематограф // Северянин И. Собрание поэз. Москва: ИзАание В.

В. Пошуканина, 1916. Т. 1. С. 98.

33. Сидор-Гібелинда О. ВіА шинку Ао трону: Жанрова мозаїка київського кінорепертуару 1910-1917 pр. у Азеркалі фільмової рубрикації // Сучасні проблеми досліАження, реставрації та збереження культурної спадщини: Наук. зб. Київ: Фенікс, 2007. Вип. IV. С. 315-323.

34. Сидор-Гібелинда О. Віра Холодна - рецепція фільмової творчості у ХХ ст. // ХуАожня культура. 
Актуальні проблеми: Наук. зб. Київ: ВиА. Аім А+С, 2005. С. 318-346.

35. Сидор-Гібелинда О. Зоря екрану скаче з вікна // КINO-КО АО. Київ, 2003. № 18. С. 89-96.

36. Сидор-Гібелинда О. Кінематограф і фрустрація // Сучасні проблеми худ. освіти в Україні: Наук. зб. Київ: Софія, 2009. Вип. V. С. 187-192.

37. Сидор-Гібелинда О. Троє кіномистців з України (Назимова, Гайдаров, Стен) // Сучасне мистецтво: Наук. 3б. Київ: Акта, 2007. С. 246-263.

38. Сидор-Гібелинда О. 400 витівок Аиявола, або Кінемо на межі нервового зриву // Сучасні проблеми Аослідження, реставрації та збереження культурної спадщини: Наук. зб. Київ, 2008. Вип. V. C. $259-271$.

39. Чуваков В. Н. Рославлев А. С // Краткая митературная энцикмопедия. - Москва: Сов. энцикмопеАия, 1971. Т. 6. С. 397, 398.

40. Шпигуни і диверсанти за роботою: 3б. статей. Київ: Соцеквидав України, 1937. 79 с.

41. Южная копейка. Киев, 1912. № 704 (10 декабря).

\section{References}

1. Blok A. Literaturnyie itogi 1907 g. [Blok A. Literary results of 1907] // Blok A. Sobranie sochineniy. Moskva, Leningrad, Gos. izdatelstwo hud. literaturi, 1962. T. 5. S. 209-232.

2. Bozhowich V. Poezia zritelnih obrazow [Bozhowich V. Poetry of visual images] // Voprosyi literaturyi [Literary questions]. Moskva, 1978. \# 5. S. 105-131.

3. Burd G. Obranets dvoh muz [Burd G. The lover two of muses] // Vitchizna [Motherland]. Ky`yv, 1968. \# 8. S. $188-193$.

4. Vaynberg I. V poiskah literaturnogo fakta [Vaynberg I. Seeking of literary fact] // Literaturnaya gazeta [Literary newspaper]. Moskva, 1970. \# 40. S. 6.

5. Vorovskiy V. Felietoiy. [Vorovsky V. A feuilletons] Moskva, 1960. 376 s.

6. Goseyko L. Istoriya ukrayn `s 'kogo kinematografa [Goseyko L. A history of Ukrainian movie]. Ky`yv: KINO-KOLO, 2005. $464 \mathrm{~s}$.

7. Yefremov S. Ivan Levy`ts`ky`j Nechuj [Efremoff S. Ivan Levitsky Nechuy]. [Ky`yv]: Slovo, 1924. $192 \mathrm{~s}$.

8. Zhuk M. Albom [Zhuk M. Album] / upor. I. I. Kozy`rod, O. S. Sheveliov. Ky`yv, My`stecztvo, 1987. $128 \mathrm{~s}$.

9. Zhuk M.: Katalog vy`stavky [Zhuk M. Catalog of the exibition] / upor. L. V. Ariupy`na,

O. M. Barkovs`ka, S. Z. Lushchik. Odesa: b. vy`d., 1993. 52 s.

10. Zhuk M. Py`s`menny`k [Zhuk M. A writer] // Dzvin [Bell]. Ky`yv, 1914. \# 4. S. 319-329.

11. Zhuk M. Portrety: Ivan Nechuj-Levy`ts`ky`j [Zhuk M. Pictures: Ivan Nechuy-Levitsky] // Ky`yv. Ky`y`v, 1988. \# 11. S. 153-156.

12. Zhuk M. Spivy zemly [Zhuk M. Singings of earth]. Cherny`gy`v: Drukarnya Gub. Zemstva, 1912. $128 \mathrm{~s}$.

13. Zorkaya N. Na rubezhe stoletiy: U istokov massovogo iskusstva Rossii 1900-1910 gg. [Zorkaya N. On the turn of the century: Origins of mass art in Russia from 1900s till 1910s]. Moskva: Nauka, 1976. 304 s.

14. Zorkaya N. «Strashnoe, pravdivoe i mstitelnoe iskusstvo...»: Osip Mandelshtam o kinematografe [«Terrible, truthful and revengeful art...»: Osip Mandelstam about movie art] // Iskusstvo kino [Art of movie]. Moskva, 1988. \# 3. S. 79-86. \# 4. S. 82-95.

15. Katalod vy`stavky pamyaty I. Levy`ts`kogo-Nechuya. 1838-1918-1928 [Catalog of exibition in memory I. Levitsky-Nechuy]. Ky`yv: Derzhtrest «Ky`yvdruk», 1928. 68 s.

16. Kashiani T. Filmyi, kotoryie meniyut mir [Kashiani T. The films which can to change of world] / per. s angl. Harkov: Gumanitarnyiy tsentr, 2018. $192 \mathrm{~s}$.

17. Kievlianin [Kyivite]. Kiev, 1913. \# 187 (7 iyulia).

18. Ky`yv: Entcy`klopedy`chny`j dovidny`k [Ky`yv: Handbook]. Ky`yv: Golovna redak`czty`ya Ukrayinskoyi Radyanskoyi Entsy'klopedii, 1981. 736 s. 
19. Lavrov D. «Svyaty`ij Ky`yv nash velyiky`j...» [Lavroff D. «Our great, saint Kyiv...»]. Ky`yv: Kry`ny'tsya, 2002. $152 \mathrm{~s}$.

20. Lindgren E. Iskusstvo kino: Vvedenie v kinovedenie [Lindgren E. A art of the film: An introduction to film appreciation] / per. s angl. Moskva: Izdatelstvo inostrannoy literaturiy, 1956. $192 \mathrm{~s}$.

21. Mandelshtam O. Kamen [Mandelshtam O. Stone]. Leningrad: Nauka, 1990. 400 s.

22. Mandelshtam O. Razgovor o Dante [Mandelshtam O. A talking about Dante] // Mandelshtam

O. Izbrannoe. Magadan: Knizhnoe izdatelstvo, 1990. S. 164-207.

23. Mandelshtam O. Sochineniya [Mandelshtam O. Works]. Moskva: Hud. literatura, 1990. T. 1. 638 s.

24. My`ronenko M. I. Nechuj-Levy`tsky`j. [My`ronenko M. I. Nechuj-Levy`tsky`j]. Harkiv:

Ukrains`ky`j robitny`k, 1930. $72 \mathrm{s.}$

25. My`slavs`ky`j V. Ky`no v Ukraine. Fakty. Filmy. Imena. [Mislavsky V. A movie in Ukraine. Facts.

Films. Names]. Harkov: Torgsin, 2005. 576 s.

26. My'hayliv Y. M. Zhuk. Harkiv: Ruh, [1930]. $32 \mathrm{~s}$.

27. Nechuj-Levy`tsky`j I. Vechir na Volody`my`rs`kij gory [Nechuy-Levitsky I. Evening in Volodimirs

Hill]. // Nechuj-Levy`ts`kij I. Tvory v 2 t. Ky`yv: Dny`pro, 1977. T. 2. S. 462-486.

28. Osip Mandelshtam i kinematograf [Osip Mandelshtam and movie] / podg. teksta, vstupl.

S. V. Vasilenko, B. S. Miaglova, Y. L. Freydlina // Pamir. Dushanbe, 1986. \# 10. S. 162-173.

29. Roslavlev A. V kinematografe [Roslavlev A. In cinema] // Chtets-deklamator: Antologia sovremennoy poezii. Kiev: Tipografia «Petr Barskiy», 1909. T. IV. S. 567.

30. Russkaya poezia nachala XX v.: Dooktyabrskiy period [A Russian poetry in beginning of XX c.: A prerevolution time]. Moskva: Hud. literatura, 1977.512 s.

31. Sadul G. Istoriya kinoiskusstva: ot ego zarozhdeniya do nashih dney [Sadoul G. The history of a movie art: from origin to modern age] / per. s frants. Moskva: Izdatelstvo inostrannoy literaturyi, 1957. $464 \mathrm{~s}$.

32. Severyanin I. Sinematograf [Severyanin I. Sinema] // Severyanin I. Sobranie poez. Moskva: Izdanie V. V. Poshukanina, 1916. T. 1. S. 98.

33. Sy`dor-Gibely`nda O. Vid shy`nku do tronu: Zhanrova mozayika ky`yvs`kogo kinorepertuaru 19101917 rr. v dzerkaly filmovoyi rubry'kacztii [Sidor-Gibelinda O. From inn to throne: Mosaics of genres of Kyivian movie-repertoire 1910-1917 in a mirror of announcements of papers] // Suchasny problemy dosly’dzhenya, restavraczty`yi ta zberezhennya kul`turnoyi spadshchy`ny: Nauk. zb. Kyiv: Feniks, 2007. Vyp. IV. S. 315-323.

34. Sy`dor-Gibely`nda O. Vira Holodna - recztepcztia filmovoyi tvorchosty u XX st. [Sidor-Gibelinda O. Vera Kholodnaya - a reception of creative works in XX c.] // Hudozhya kul tura. Aktual ny problemy: Nauk. zb. Ky`yv: Vy`d. Dim A+C, 2005. S. 318-346.

35. Sy`dor-Gibely`nda O. Zorya ekranu skache z vikna [Sidor-Gibelinda O. Dawn of movie jump from window] // KINO-KOLO [Cinema-Circle]. Ky`yv, 2003. \# 18. S. 89-96.

36. Sy`dor-Gibely`nda O. Kinematograf i frustracztsia [Sidor-Gibelinda O. A movie and frustration] // Suchasni problemy hud. osvity v Ukrayini: Nauk. zb. Ky`yv: Sofia, 2009. Vy`p. V. S. 187-192.

37. Sy`dor-Gibely`nda O. Troye kinomy`cztiv z Ukrayiny (Nazimova, Gaydarov, Sten) [Sidor-Gibelinda

O. The three movie-masters from Ukraine (Nazimova, Gaydaroff, Sten)] // Suchasne my`stecztvo: Nauk.

zb. Ky`yv: Akta, 2007. S. 246-263.

38. Sy`dor-Gibely`nda O. 440 vy`tivok dy`yavola, abo Kinemo na mezhy nervovogo zry`vu [Sidor-

Gibelinda O. 440 diabolical extravagances or Movie on the verge of a nervous breakdown] // Suchasny problemy doslidzhennya, restavracztiyi ta zberezhennya kul turnoyi spadshchyny: Nauk. zb: Ky`yv, 2008. Vy`p. V. S. 259-271.

39. Chuvakov V. N. Roslavlev A. S. // Kratkaya literaturnaya entsiklopediya. Moskva: Sov. entsiklopediya, 1971. T. 6. S. 397, 398.

40. Spy`guny i dy`versanty za robotoyu: Zb. statej [Spies and saboteurs in working]. Ky`yv: Socztekvy`dav Ukrayiny, 1937. $79 \mathrm{~s}$.

41. Yuzhnaya kopeyka [South copek]. Kiev, 1912. \# 704 (10 dekabrya). 


\section{Сидор О. В. Кинематограф в художественной митературе начала ХX века}

Анотация. Исследуются отражения раннего киноискусства в украинской поэзии и прозе этого времени (на примерах, ранее не анализировавшихся). Введение в научный обиход новых материалов обогатит историю кинематографа вообще (также историю украинского искусства), дополнит ее подробностями и уточнениями.

Ключевые слова: символизм, нарратив, очерк, китч.

\section{Sidor $O$. $V$. A movie-art in the fiction-literature of the "fin de siecle»}

Abstract. The article deal with the reflections of the young movie-art in the Ukrainian poetry and prose of that age (at rarely examples). Introduction new documents into scientific use will enrich a history of a movie-art generally (and also a history of Ukrainian art), will add new facts and provide more details and clarifications.

Keywords: Symbolism, narration, sketch, kitch. 